\title{
Salinity changes and anoxia resulting from enhanced run-off during the late Permian global warming and mass extinction event
}

\author{
Elsbeth E. van Soelen ${ }^{1}$, Richard J. Twitchett ${ }^{2}$, and Wolfram M. Kürschner ${ }^{1}$ \\ ${ }^{1}$ University of Oslo, Departments of Geosciences, P.O. Box 1047 Blindern, 0316 Oslo, Norway \\ ${ }^{2}$ Natural History Museum, Earth Sciences Department, London, SW7 5BD, UK
}

Correspondence: Elsbeth E. van Soelen (evansoelen@gmail.com)

Received: 20 October 2017 - Discussion started: 25 October 2017

Revised: 13 February 2018 - Accepted: 13 March 2018 - Published: 9 April 2018

\begin{abstract}
The late Permian biotic crisis had a major impact on marine and terrestrial environments. Rising $\mathrm{CO}_{2}$ levels following Siberian Trap volcanic activity were likely responsible for expanding marine anoxia and elevated water temperatures. This study focuses on one of the stratigraphically most expanded Permian-Triassic records known, from Jameson Land, East Greenland. High-resolution sampling allows for a detailed reconstruction of the changing environmental conditions during the extinction event and the development of anoxic water conditions. Since very little is known about how salinity was affected during the extinction event, we especially focus on the aquatic palynomorphs and infer changes in salinity from changes in the assemblage and morphology. The start of the extinction event, here defined by a peak in spore: pollen, indicating disturbance and vegetation destruction in the terrestrial environment, postdates a negative excursion in the total organic carbon, but predates the development of anoxia in the basin. Based on the newest estimations for sedimentation rates, the marine and terrestrial ecosystem collapse took between 1.6 and $8 \mathrm{kyr}$, a much shorter interval than previously estimated. The palynofacies and palynomorph records show that the environmental changes can be explained by enhanced run-off and increased primary productivity and water column stratification. A lowering in salinity is supported by changes in the acritarch morphology. The length of the processes of the acritarchs becomes shorter during the extinction event and we propose that these changes are evidence for a reduction in salinity in the shallow marine setting of the study site. This inference is supported by changes in acritarch distribution, which suggest a change in palaeoenvironment from open marine
\end{abstract}

conditions before the start of the extinction event to more nearshore conditions during and after the crisis. In a period of sea-level rise, such a reduction in salinity can only be explained by increased run-off. High amounts of both terrestrial and marine organic fragments in the first anoxic layers suggest that high run-off, increased nutrient availability, possibly in combination with soil erosion, are responsible for the development of anoxia in the basin. Enhanced run-off could result from changes in the hydrological cycle during the late Permian extinction event, which is a likely consequence of global warming. In addition, vegetation destruction and soil erosion may also have resulted in enhanced run-off. Salinity stratification could potentially explain the development of anoxia in other shallow marine sites. The input of freshwater and related changes in coastal salinity could also have implications for the interpretation of oxygen isotope records and seawater temperature reconstructions at some sites.

\section{Introduction}

The late Permian extinction event was the most severe global crisis of the Phanerozoic in terms of both taxonomic loss and ecological impact (e.g. McGhee et al., 2012). The current consensus is that the extinction was likely due to global warming and associated environmental changes caused by $\mathrm{CO}_{2}$ emissions from Siberian Trap volcanic activity because of the close timing between the volcanic activity and the extinction event (e.g. Burgess et al., 2017; Burgess and Bowring, 2015). Most studies of the late Permian extinction have inferred that expanding marine anoxia (e.g. Wig- 
nall and Hallam, 1992) was a key biotic factor causing marine extinction and ecosystem collapse. There are different theories to explain the spreading of anoxia, which affected both deep and shallow sites (e.g. Bond and Wignall, 2010; Isozaki, 1997; Wignall and Twitchett, 1996). A weakened temperature gradient between Equator and pole would have slowed ocean circulation and may have facilitated expansion of the oxygen minimum zone (Hotinski et al., 2001). Increased weathering and detrital input (Algeo and Twitchett, 2010) and soil erosion (Sephton et al., 2005) led to enhanced terrestrial matter input in marine sections, and may also have contributed to eutrophication and in stratified waters led to hypoxia or anoxia (Sephton et al., 2005). Other factors that are thought to have played important roles in the extinction are elevated water temperatures (e.g. Sun et al., 2012) and ocean acidification (Clapham and Payne, 2011). One important environmental parameter that has received relatively little attention is salinity, even though low-salinity ocean conditions were once considered to be a leading cause of the marine extinction (Fischer, 1964; Stevens, 1977). Furthermore, potential impacts of changes in salinity, which might be expected from enhanced discharge of freshwater into shelf seas (Winguth and Winguth, 2012), have been largely ignored.

Microfossils of marine algae are excellent recorders of environmental change in the water column. Of these, the organic-walled cysts of dinoflagellates have proven especially useful in palaeoenvironmental studies (e.g. Ellegaard, 2000; Mertens et al., 2009, 2012; Mudie et al., 2001, 2002; Sluijs and Brinkhuis, 2009; de Vernal et al., 2000). While dinocysts are absent or sparse in Palaeozoic deposits, acritarchs are commonly recorded (e.g. Tappan and Loeblich, 1973), even during the late Permian when acritarch diversity was declining (Lei et al., 2013a). Acritarchs are a group of microfossils of organic composition and unknown affinity (Evitt, 1963). Many acritarchs are, however, considered to be phytoplankton, and some are thought to be precursors of modern dinoflagellate cysts (e.g. Lei et al., 2013a; Servais et al., 2004). Several studies in East Greenland have reported fluctuating abundances of acritarchs during the late Permian and Early Triassic (e.g. Balme, 1979; Piasecki, 1984; Stemmerik et al., 2001), but very few late Permian studies have documented the relative abundance of the different genera of aquatic palynomorphs (for example, Shen et al., 2013). Similar to dinocysts, acritarch morphology has been linked to environmental conditions, and acritarchs with longer processes are generally more abundant in more open marine settings (Lei et al., 2012; Stricanne et al., 2004). Both dinocyst and acritarch studies show that salinity might be an important factor that influences cyst morphology (Servais et al., 2004). It is thought that the longer processes in higher salinities stimulate clustering with other cysts or particles in the water column, and thus enhance sinking to the seafloor (Mertens et al., 2009).

The rock record of Jameson Land, East Greenland, has provided key insights into marine environmental changes during the late Permian extinction event. Previous work on this section by Twitchett et al. (2001) showed that collapse of marine and terrestrial ecosystems was synchronous and took between 10 and $60 \mathrm{kyr}$. Palynological work by Looy et al. (2001) showed that the terrestrial ecosystem collapse is characterized by a distinct rise in spores, indicative of the loss of woodland and increase in disturbance taxa. The onset of anoxic conditions is not as abrupt at this location as seen in some other sections, but instead Wignall and Twitchett (2002) found unusual alternating patterns of bioturbated and laminated siltstones in the top of the Schuchert Dal Formation and lowest part of the Wordie Creek Formation (Fig. 1). In a recent study, Mettam et al. (2017) showed that rapidly fluctuating redox conditions occurred during the late Permian extinction, while sedimentological observations imply that sea level was rising in this period. Estimations of sedimentation rates indicate that each bioturbated-laminated rock interval, which are between 2 and $10 \mathrm{~cm}$ thick, have been deposited in a period of 50-1000 years (Mettam et al., 2017).

To study the environmental conditions associated with the deposition of these sediments we look in detail at a short $(9 \mathrm{~m})$ interval covering the late Permian extinction and the boundary between the Schuchert Dal and Wordie Creek formations. Palaeoenvironment is studied by looking at variations in the palynofacies (organic particles) and the acritarch assemblage. In addition we present a record of morphological changes within the acritarch Micrhystridium. Run-off and erosion, salinity, sea-level fluctuations and temperature rise are discussed as possible reasons for the changing environmental conditions.

\section{Geological setting and stratigraphy}

Samples were collected at the Fiskegrav location of Stemmerik et al. (2001), an outcrop in East Greenland $\left(71^{\circ} 32^{\prime} 01.6^{\prime \prime} \mathrm{N}, 024^{\circ} 20^{\prime} 03.0^{\prime \prime} \mathrm{W}\right)$, in a small stream section on the east side of Schuchert Dal (Fig. 1). The section was deposited within a relatively narrow, north-south-oriented basin (Stemmerik et al., 2001; Wignall and Twitchett, 2002). Active rifting and rapid subsidence has resulted in the deposition of one of the most expanded Permian-Triassic sections. At the Fiskegrav location there are no obvious breaks in sedimentation, even though large erosive channels exist in Permian-Triassic sections in more northern locations (Twitchett et al., 2001; Wignall and Twitchett, 2002).

The Fiskegrav section shows a transition from the Schuchert Dal Formation into the Wordie Creek Formation. The Permian-Triassic boundary, defined by the first occurrence of the conodont Hindeodus parvus (Yin, 1996), is located at $23.5 \mathrm{~m}$ above the base of the Wordie Creek Formation (Twitchett et al., 2001). This study focuses on a ca. $9 \mathrm{~m}$ section interval including the late Permian extinction and the formation boundary (Fig. 1). The upper part of the Schuchert Dal Formation consists of blocky (bioturbated) micaceous 

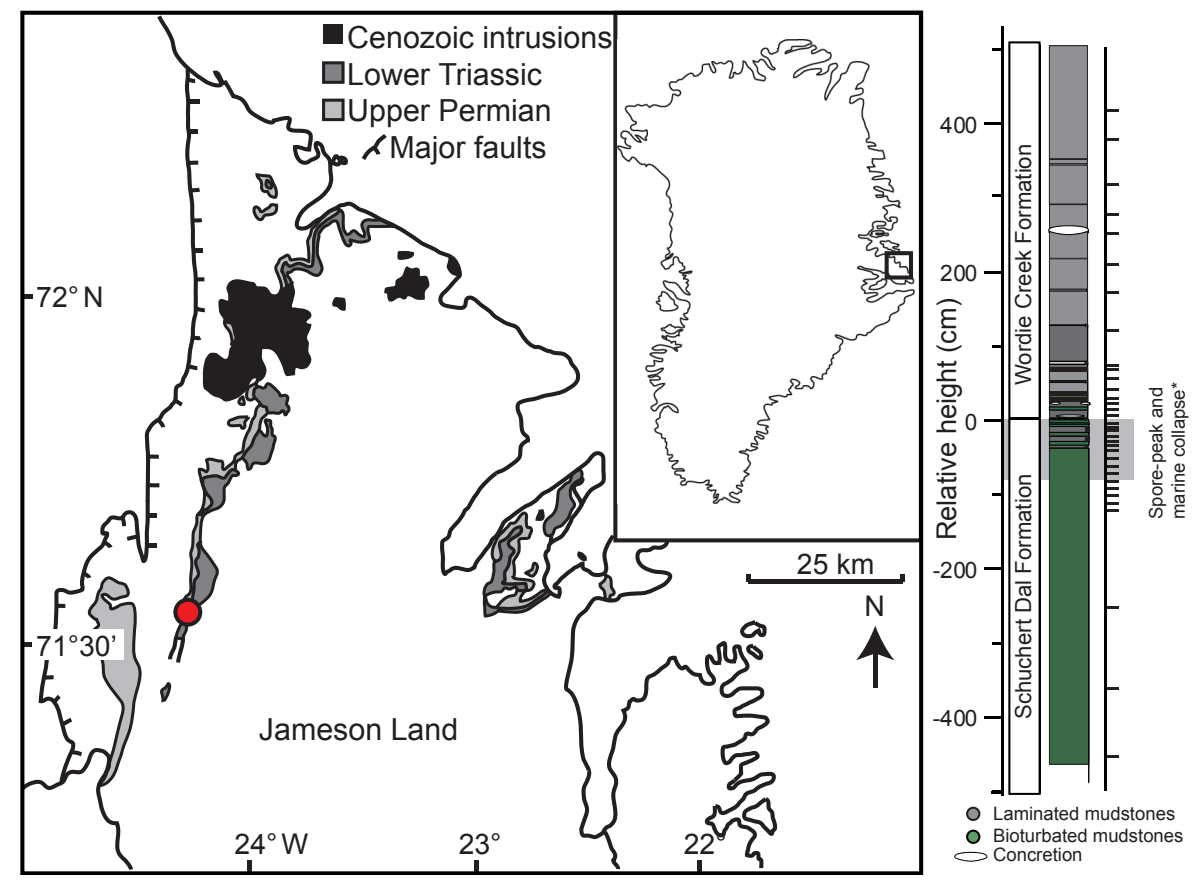

Figure 1. Map of Jameson Land, East Greenland (adapted from Piasecki, 1984). The location of the studied section is indicated with a red circle. The right panel shows the lithology of the studied section and sample depths. (* is the spore peak after Looy et al., 2001; marine collapse after Twitchett et al., 2001).

greenish mudstones (muddy siltstones), whereas the lower Wordie Creek Formation consists mainly of laminated dark grey mudstones (clay siltstones) that often contain framboidal pyrite (Twitchett et al., 2001; Wignall and Twitchett, 2002). The extinction event occurs in the upper metres of the Schuchert Dal Formation, and the start of the biotic crisis is synchronous in marine and terrestrial ecosystems (Looy et al., 2001; Twitchett et al., 2001). For more details on biostratigraphy see Mettam et al. (2017), Stemmerik et al. (2001) and Twitchett et al. (2001).

\section{Materials and method}

\subsection{Material}

A total of 36 samples were collected from the top $4.5 \mathrm{~m}$ of the Schuchert Dal Formation and the lower $4.2 \mathrm{~m}$ of the Wordie Creek Formation. Sample resolution is highest $(10 \mathrm{~cm}$ intervals) in the $2.5 \mathrm{~m}$ interval covering the formation boundary and the extinction event. Depths are given in metres, relative to the formation boundary between the Schuchert Dal and Wordie Creek formations. Some of the samples used in this study were also analysed by Mettam et al. (2017) during their study of changes in redox conditions at the formation boundary.

\subsection{Palynofacies and palynological analysis}

Samples (of ca. $5 \mathrm{~g}$ ) were crushed, and a tablet with a known number of lycopodium spores was added to allow quantification of organic particles and palynomorphs. Samples were then treated with hydrochloric acid and hydrofluoric acid to remove carbonates and silicates, and subsequently sieved through $7 \mu \mathrm{m}$ sieves. Heavy liquid separation was used to remove heavy minerals like pyrite. The residue, containing palynomorphs and other organic particles, was mounted onto microscope slides. Material was counted using a Leitz Diaplan microscope and an AxioCam ERc $5 \mathrm{~s}$ camera attached to a computer with Zen microscope software (Zen 2 lite, 2011). A minimum of 300 particles per sample were counted for palynofacies analyses. Aquatic palynomorphs were counted to reach 100 specimens when abundant and at least 30 specimens when abundance was low. Still, due to low abundances during the biotic crisis, in some samples counts were below 30 (these six samples are indicated in Fig. 4).

\subsection{Acritarch measurements}

The genus Micrhystridium includes many species, of which ca. 20 are known from the Permian-Triassic interval, which differ in their body size, number of processes and process length (Lei et al., 2013a; Sarjeant, 1970). Only those with a spherical central body and many $(>10)$ simple processes with closed tips were included in this study (i.e. the M. breve group, according to Lei et al., 2013a). Thus, amongst oth- 


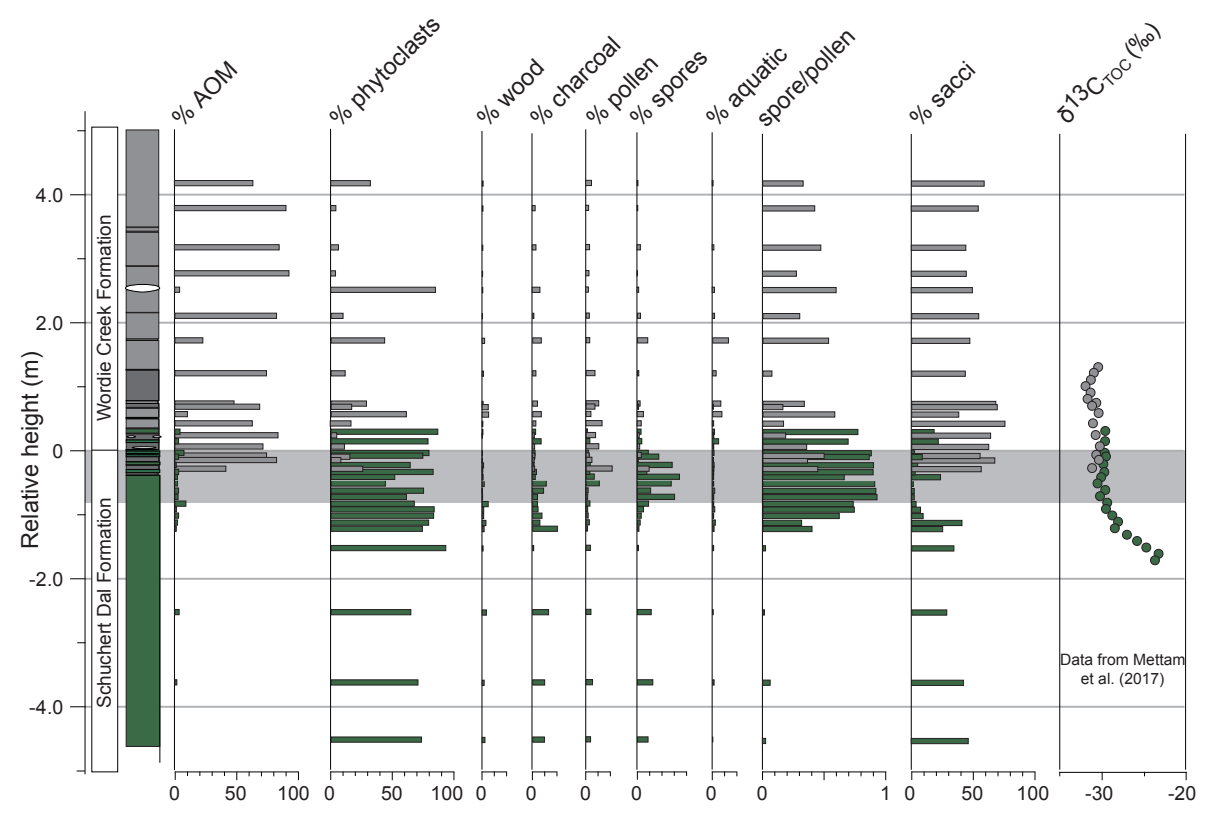

Figure 2. Change in major groups of palynofacies. AOM: amorphous organic matter. The grey shaded box highlights the biotic crisis as defined by the high spore : pollen ratios, which are indicative for the disappearance of forest communities. Green shading indicates data from bioturbated rocks; grey shading indicates data from laminated rocks. Grey horizontal bar indicates the extinction interval, based on high spore : pollen ratios.

ers, M. pentagonale was excluded. Specimens were excluded if they were too damaged (folded or broken) to allow measurements. To counteract the effects of compression (which can make the body look longer), body size was calculated from the average of two linear measurements perpendicular to each other. The choice of processes was limited due to compaction of the acritarchs. If more than three processes were available for measurement, a focal plane was chosen that showed the most and best preserved processes, from which we measured the three longest, following the methodology of Mertens et al. (2012). The aim was to measure 2030 specimens per sample, but acritarch concentrations were low during the biotic crisis interval, and therefore five samples had lower counts (indicated in Fig. 6).

\section{Results}

\subsection{Palynofacies}

The most abundant organic particles are phytoclasts and amorphous organic matter (AOM), which together comprise 45 to $90 \%$ of the palynofacies (Fig. 2). Phytoclasts are dominant in the bioturbated samples in the lower part of the section, while AOM dominates the palynofacies in the laminated intervals. Other terrestrially derived organic (wood fragments and charcoal) particles make up a small portion $(<20 \%)$ of the palynofacies and are not influenced by the alternating anoxic-oxic depositional conditions (Fig. 2). Palynomorphs were divided into three groups: pollen, spores and aquatic palynomorphs. Pollen abundance relative to other palynofacies is higher in the upper $0.5 \mathrm{~m}$ of the Schuchert Dal Formation and lowest metre of the Wordie Creek Formation (5$20 \%$ ), which is mainly caused by the high number of pollen fragments (sacci) during and following the extinction event (Fig. 2). Spores have the highest abundance in the upper metre of the Schuchert Dal Formation (up to $35 \%$ ), where the spore : pollen ratio is also the highest. Aquatic palynomorphs (acritarchs and other algal remains like Tasmanites and $C y$ matiosphaera) make up a very small fraction of the palynofacies in the Schuchert Dal Formation $(<2 \%)$, but become relatively more abundant in the Wordie Creek Formation (up to $14 \%)$.

\subsection{Aquatic palynomorphs}

Although Permian acritarch diversity is considered low, an overview of Permian phytoplankton by Lei et al. (2013a) showed a richness of about 20-30 genera during most of the Permian, with acritarchs belonging to the genera $\mathrm{Mi}$ crhystridium and Veryhachium being the most common (Lei et al., 2013a, b; Sarjeant and Stancliffe, 1994). Since cysts are generally small in size it is difficult to study them under the light microscope and identification at species level can be difficult (Sarjeant, 1970). Several revisions and simplifications have been proposed for the genera (Lei et al., 2013b; Sarjeant and Stancliffe, 1994). We follow the simple classification scheme proposed by Lei et al. (2013b), in which different species of acritarchs are grouped together, based on ge- 

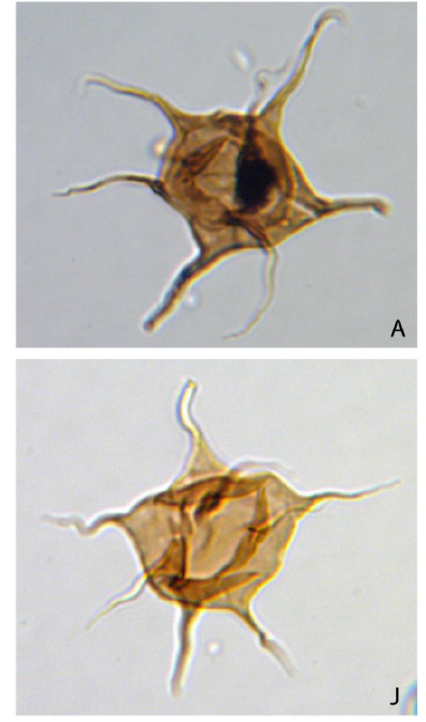

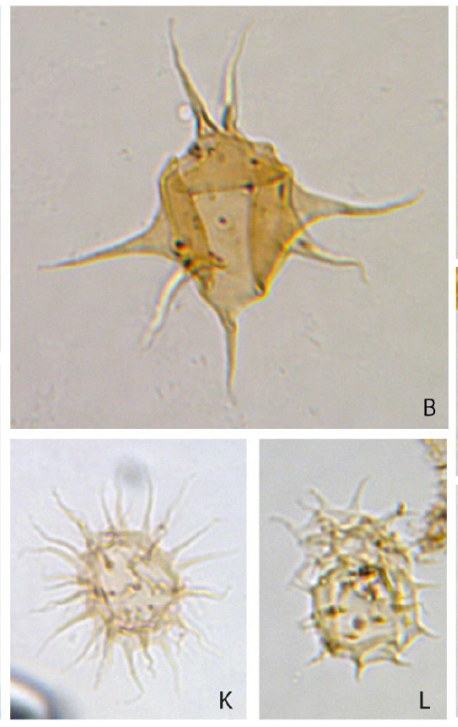

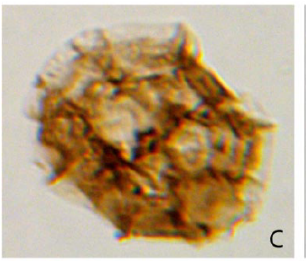
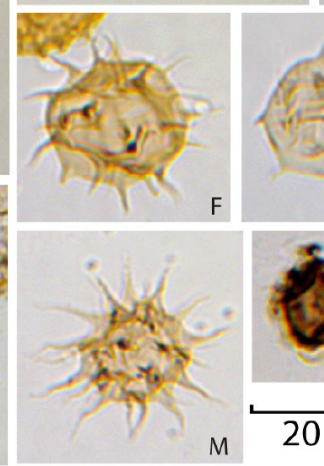

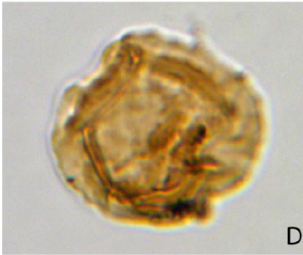

D

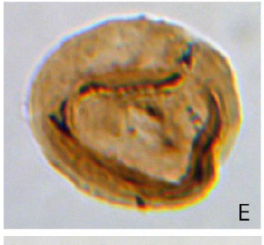

E
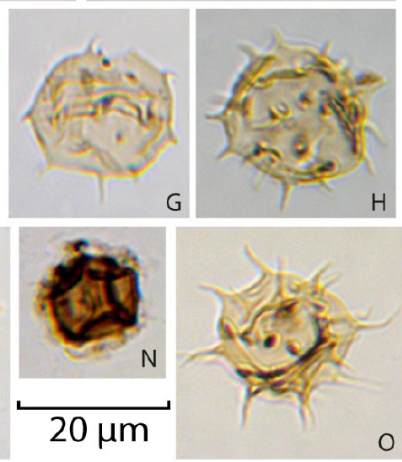

$\mathrm{H}$
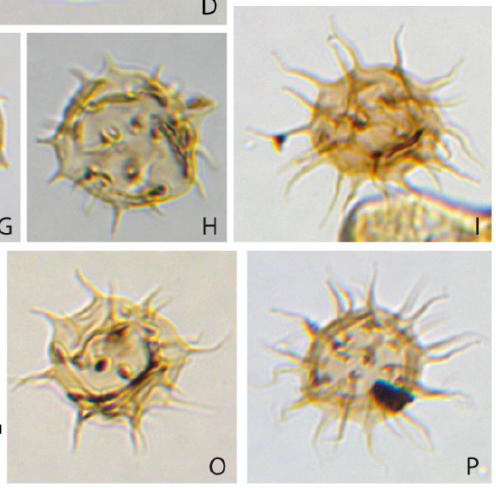

Figure 3. Aquatic palynomorph from the studied interval. (a) M. pentagonale group, (b) V. laidii group, (c) Cymatiosphaera sp., (d, e) leiospheres, (f-i) M.breve group, (j) M. pentagonale group, (k-m) M. breve group, (n) Cymatiosphaera sp. and (o, p) M. breve group.

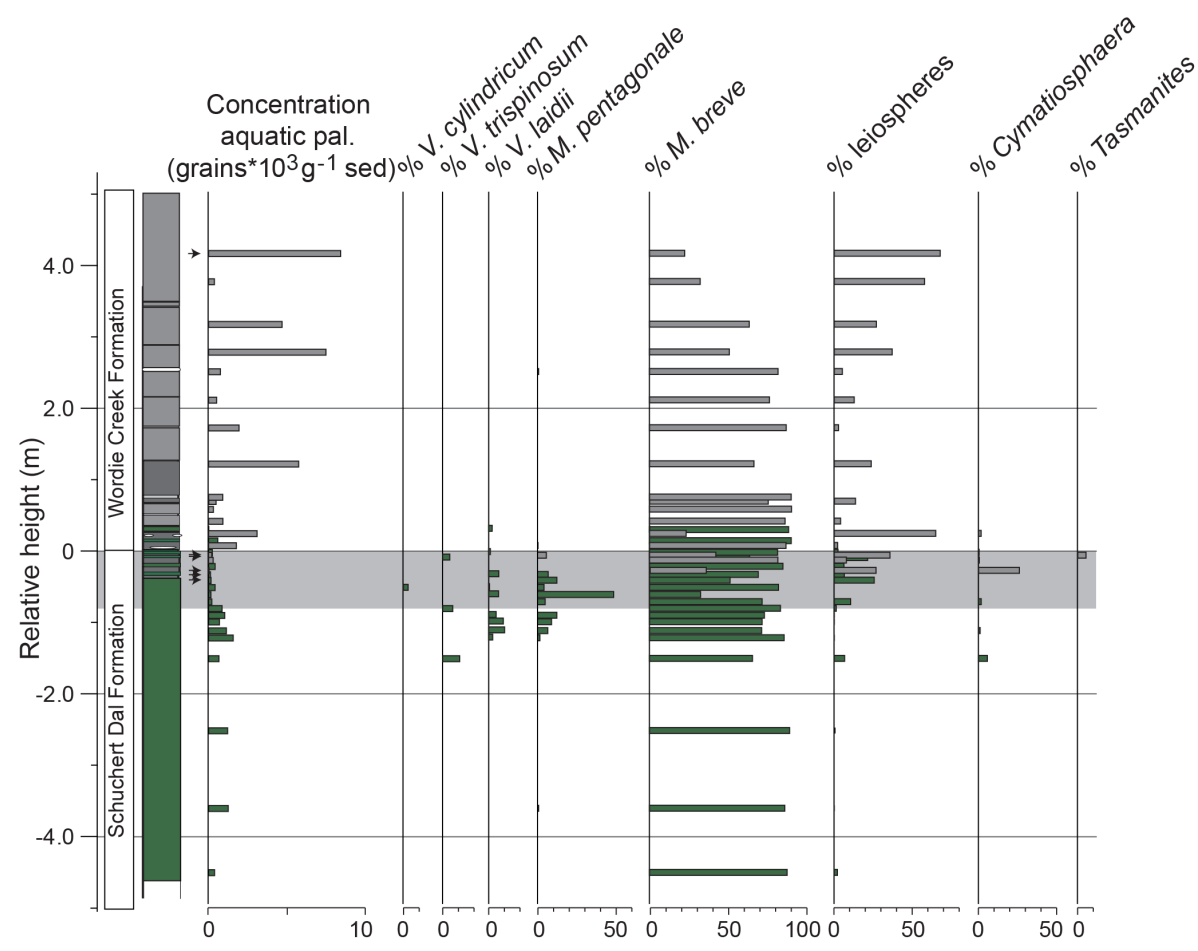

Figure 4. Concentrations of all aquatic palynomorphs and relative abundances of specific acritarch and prasinophyte groups. Arrows indicate intervals with low counts $(<20)$. Green shading indicates data from bioturbated rocks; grey shading indicates data from laminated rocks. The grey horizontal bar indicates the extinction interval, based on high spore : pollen ratios.

ometrical shape of the acritarchs. Photos of selected aquatic palynomorphs are shown in Fig. 3.

Concentrations of aquatic palynomorphs were on average ca. 4 times higher in the laminated rocks compared to the bioturbated rocks (Fig. 4). Acritarch abundance also declines during the extinction event. The majority (25-100\%) of the acritarchs belong to the Micrhystridium breve group (Fig. 4). This group includes all acritarchs with a spherical central body and numerous processes. The Veryhachium laidii group (acritarchs with a rectangular central body shape), the 


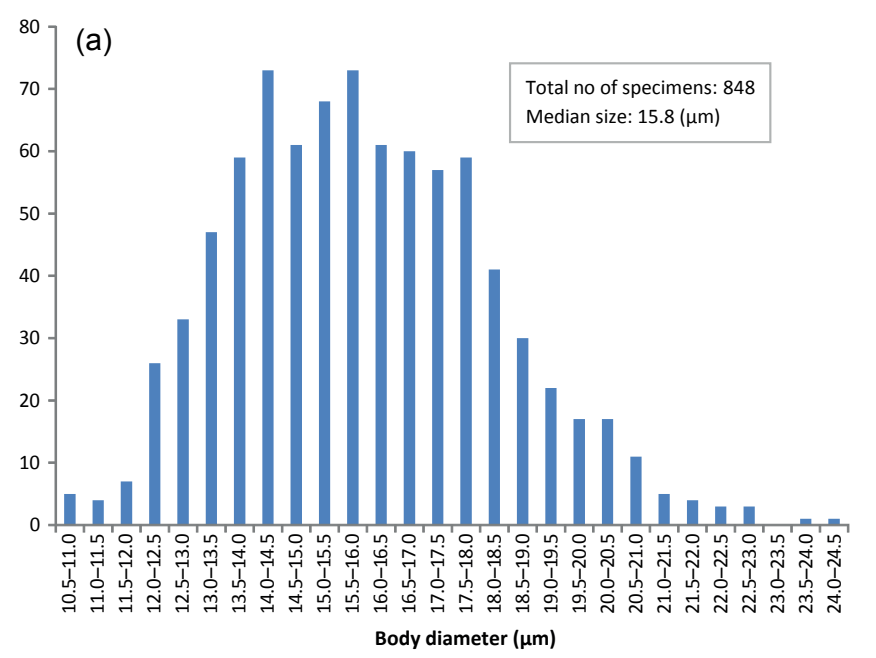

Figure 5. Size frequency of body diameter (a) and process length (b).

V. trispinosum group (triangular shape), V. cylindricum group (ellipsoidal shape) and M. pentagonale group (pentagonal or hexagonal shape) were mostly found in bioturbated intervals of the upper part of the Schuchert Dal Formation, especially just before and during the extinction interval (Fig. 4). The leiospheres include all aquatic palynomorphs with a spherical shape and either a smooth surface or with small ornamentation, but no processes. The highest abundances (up to $70 \%$ ) of leiospheres are found in the laminated sediments of the Wordie Creek Formation (Fig. 4). Cymatiosphaera are rare in the record and found in both the oxidized siltstones of the Schuchert Dal Formation, but also in some intervals in the laminated siltstones. Tasmanites were found only in one sample, also during the marine extinction phase. The apparent relatively higher abundance of Cymatiosphaera and Tasmanites in the top of the Schuchert Dal Formation is a consequence low total count of the aquatic palynomorphs during the extinction event. The most diverse samples were found in the bioturbated rocks of the upper metre of the Schuchert Dal Formation, an interval that partly overlaps with the extinction interval.

The Micrhystridium group has a diverse morphology, and shows variation in vesicle size and number of processes. Most of the measured specimens are very similar to the species M. breve as described by Jansonius (1962) in both the number and shape of the processes. However, the size of the central body and the length of the processes of many of the measured acritarchs fall outside of the defined size range of $M$. breve. Variability in process length within one specimen was generally small (in almost $80 \%$ of the specimen measured $<2 \mu \mathrm{m}$ and in only $7 \%$ of the cases $>3 \mu \mathrm{m}$ ) (see also Table S4 in the Supplement). The distributions of both body size and process length are unimodal (Fig. 5), which suggests that the measured specimens all belong to a single species of Micrhystridium. Body size is variable, with (b)

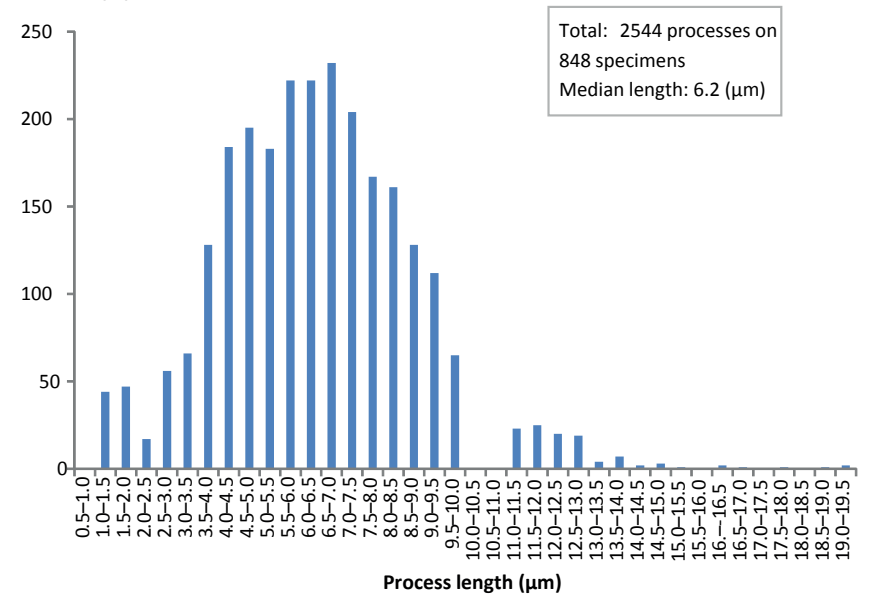

a decrease around $-150 \mathrm{~cm}$ from 16.5 to $13.5 \mu \mathrm{m}$, followed by a gradual increase throughout the extinction event up to $19 \mu \mathrm{m}$ at $75 \mathrm{~cm}$, followed by an abrupt decrease to $14 \mu \mathrm{m}$, after which body size stabilizes between 14.5 and $16 \mu \mathrm{m}$. In the $2 \mathrm{~m}$ interval spanning the formation boundary, acritarchs in the laminated rocks are on average larger compared to those in the bioturbated rocks; however, this is not consistently true further up or down the section (Fig. 6). The average process length first increases before the start of the extinction from an average 7.7 at $-450 \mathrm{~cm}$ to $11.5 \mu \mathrm{m}$ at $-250 \mathrm{~cm}$, after which processes gradually become shorter down to a minimum of around $5 \mu \mathrm{m}$ during the extinction event. Processes then remain shorter through to the top of the studied section. Process length not only changes in absolute terms but also relative to the size of the body.

\section{Discussion}

\subsection{The extinction event and onset of anoxia}

Consistent with the results of Looy et al. (2001), we find a strong increase in spores, relative to pollen, in the upper Schuchert Dal Formation (Fig. 2). Since this peak in spores coincides with the interval of marine ecosystem collapse defined by Twitchett et al. (2001), we define the period with the highest spore : pollen ratios as the extinction interval. Twitchett et al. (2001) found large changes in marine plankton abundance in their study of the Fiskegrav section, with a bloom just before the disappearance of trace fossils, followed by almost complete absence of acritarchs immediately after the collapse of the marine ecosystem. This phytoplankton bloom is not obvious in our higher-resolution data, and may simply be an artefact of the relatively low-resolution sampling of Twitchett et al. (2001), but the number of acritarchs is indeed greatly reduced during the biotic crisis (Fig. 4). The peak in spore : pollen and decrease in acritarch abundance occurs in 


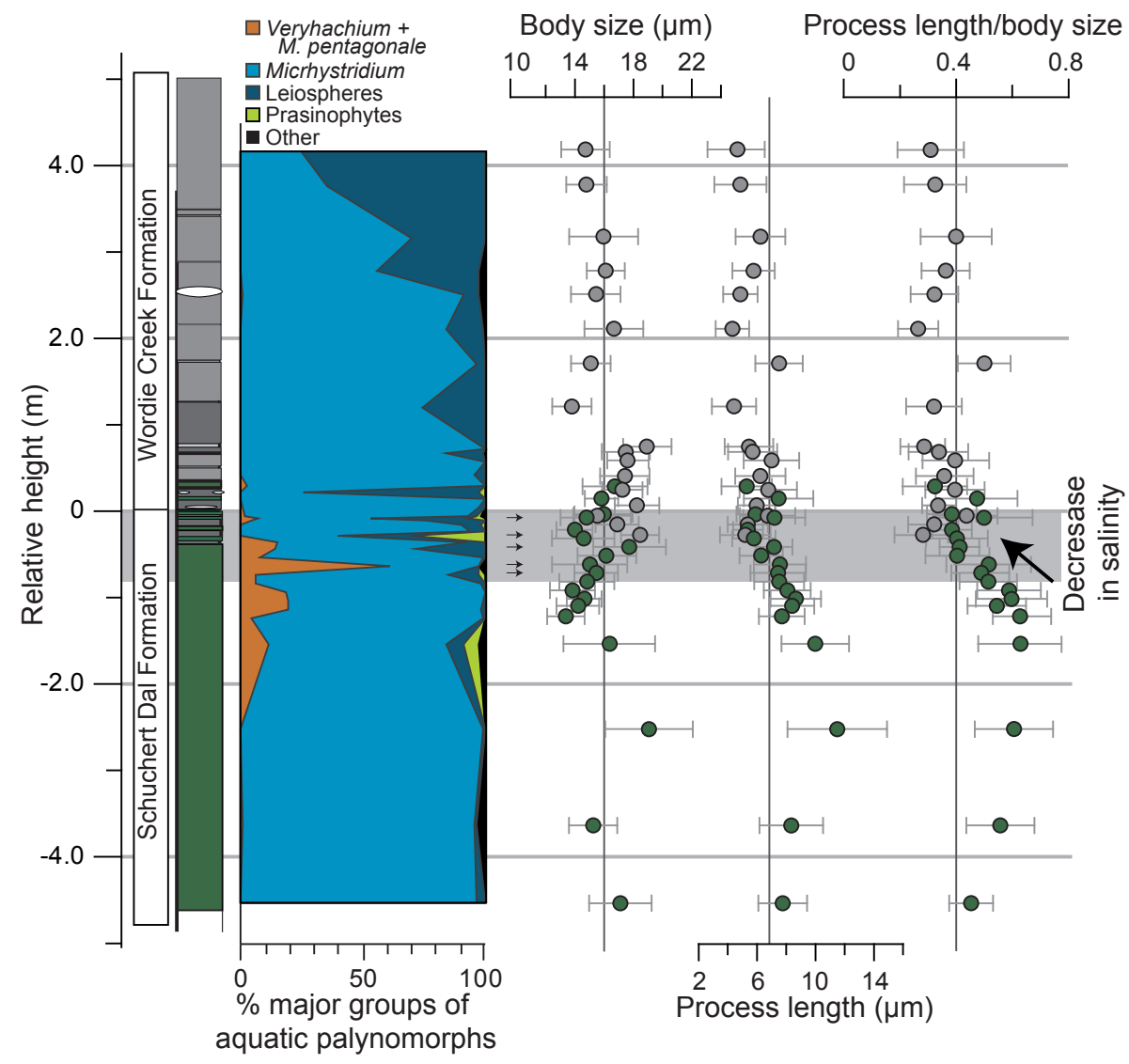

Figure 6. Changes in acritarch abundance and morphology. The left-hand panel summarizes the main groups of aquatic palynomorphs. On the right, body size, process length and process length relative to body size are shown. Green shading indicates data from bioturbated rocks; grey shading indicates data from laminated rocks. The grey bar indicates the extinction interval, based on high spore : pollen ratios. The five small black arrows indicate samples in which the number of specimens used for measurements was low (4-16 specimens).

an interval of ca. $0.8 \mathrm{~m}$, which is comparable to the interval found by Twitchett et al. (2001) for marine and terrestrial ecosystem collapse. Twitchett et al. (2001) estimated the collapse to have taken between 10 and $60 \mathrm{kyr}$; however, recently improved estimations of sedimentation rates in the Fiskegrav section (Mettam et al., 2017) now give an estimated duration of between 1.6 and $8 \mathrm{kyr}$ for the marine and terrestrial ecosystem collapse.

During the start of the biotic crisis, rocks remain bioturbated but within the upper $0.5 \mathrm{~m}$ of the Schuchert Dal Formation there are intervals with laminated rocks (Fig. 2), indicative for anoxia (Twitchett et al., 2001). AOM, which is structureless organic matter, is dominant in the laminated rocks. AOM can derive from degraded macrophyte, phytoplankton or higher plant tissue, or it may also be bacterially derived (Tyson, 1995). Anoxic conditions can stimulate the production of marine AOM (Pacton et al., 2011), but also result in better preservation after sedimentation (Tyson, 1995). The relative proportions of $\mathrm{AOM}$ versus phytoclasts thus indicate the amount of oxygenation of the depositional environment (Tyson, 1995). A recent high-resolution study of the $\delta^{13} \mathrm{C}$ of total organic carbon (TOC) by Mettam et al. (2017) shows a negative shift of 5-6\% that begins $1.80 \mathrm{~m}$ below the top of the Schuchert Dal Formation at Fiskegrav (Fig. 2). The onset of this negative excursion coincides closely with the last occurrence of Permian macroinvertebrate fossils (Mettam et al., 2017), but predates the collapse of marine and terrestrial ecosystems defined by disappearance of bioturbation. Mettam et al. (2017) record a small, but consistent, offset in $\delta^{13} \mathrm{C}$ values between the laminated and bioturbated intervals (Fig. 2). This offset can be explained by the differences in organic matter source, which is mostly phytoclasts (terrestrial) in the bioturbated intervals while AOM (marine and terrestrial) dominates in the laminated intervals. However, the main shift is not associated with major changes in the palynofacies, and occurs in a part of the section where the palynofacies mainly consist of terrestrially derived organic matter (Fig. 2). This negative shift in carbon isotopes associated with the late Permian extinction event is recognized worldwide (e.g. Korte and Kozur, 2010) and usually precedes the extinction event (e.g. Burgess and Bowring, 2015; Korte and Kozur, 2010). It has been interpreted as resulting from 
atmospheric changes in $\delta^{13} \mathrm{C}$ values, which can be directly, or indirectly, related to Siberian Trap volcanism (e.g. Cui and Kump, 2015; Svensen et al., 2009).

Mettam et al. (2017) studied redox conditions in the same section and showed that conditions became potentially anoxic and ferruginous $\left(\mathrm{Fe}^{2+}\right.$-rich) in the laminated intervals near the formation boundary. Within the lowermost Wordie Creek Formation, from 0.6 to $0.7 \mathrm{~m}$ above the formation boundary, anoxic conditions are confirmed by Fe speciation (Mettam et al., 2017). Since the extinction started before conditions became ferruginous, spreading anoxia cannot be the main cause for the marine biotic crisis in the Fiskegrav section. Grasby et al. (2015) distinguished three phases of extinction in the shallow marine sequence of Festningen (Svalbard): first is the loss of carbonate macrofauna, followed by loss of siliceous sponges, and finally a loss of all trace fossils. Thus, similar to what is observed in East Greenland, the first laminated sediments do not represent the start of the biotic crisis. This is unsurprising as expanding marine hypoxia is a predicted consequence of global warming, which was probably caused by elevated $\mathrm{CO}_{2}$ flux from Siberian Trap volcanism (Benton and Twitchett, 2003; Grard et al., 2005). Therefore, extinctions that occurred prior to the appearance of widespread anoxia were more likely due to the direct short-term effects of volcanic activity (e.g. metal toxicity), or the more immediate effects of $\mathrm{CO}_{2}$ rise or temperature increase.

The laminated rocks are associated with a higher number of pollen fragments (Fig. 2), which could be an indication for elevated terrestrial organic matter input (e.g. soil erosion), while the higher amount of AOM can be partly explained by terrestrial organic matter input, and partly by increased marine productivity and better preservation of organic matter due to low-oxygen conditions. Increased weathering and run-off are expected consequences of atmospheric and hydrological changes associated with global warming. Algeo and Twitchett (2010) demonstrated that sediment accumulation rates greatly increased in shallow shelf seas in the latest Permian and earliest Triassic, consistent with enhanced weathering and run-off, and Sephton et al. (2005) found evidence for large-scale soil erosion.

\subsection{Sea-level and salinity changes}

If the laminated rocks are indeed a consequence of enhanced run-off, this is expected to also affect marine environmental conditions, such as a decrease in (surface) salinity. At the same time, sea-level fluctuations at and near the boundary need to be considered since these would also affect marine environmental conditions and could potentially affect salinity. The Fiskegrav section has preserved aquatic palynomorphs well, and their diversity, distribution and morphology can provide valuable information on marine environmental changes. Palaeozoic studies have shown that acritarch diversity is generally higher in deeper, more distal settings (e.g. Lei et al., 2012; Stricanne et al., 2004). In addition, different studies have shown that Veryhachium favoured more open marine settings, while Micrhystridium favoured nearshore environments (e.g. Wall, 1965; Lei et al., 2012). It is possible that some of the leiospheres in the Fiskegrav section belong to the genus Leiosphaeridia, as the dimensions are comparable to L. microgranifera and L. minutissima that were found in Chinese Permian-Triassic sections (Lei et al., 2012), but the small ornamentations on both of those species are different (Fig. 3). In these Chinese Permian sections the Leiosphaeridia are associated with deeper, more open marine waters (Lei et al., 2012). Conversely, studies of early Palaeozoic acritarchs show that, in general, leiospheres, or sphaeromorphs, are most frequent in proximal environments (Li et al., 2004; Stricanne et al., 2004). The leiosphere group might be polyphyletic and some species might have prasinophyte affinities (Colbath and Grenfell, 1995), which complicates their use for environmental reconstructions. Whatever the biological origin of the leiosphere is, at this study site they apparently favoured the palaeoenvironmental conditions associated with the deposition of the laminated rocks, starting during the extinction event.

In the Fiskegrav section, the decline in diversity from the upper Schuchert Dal Formation to the Wordie Creek Formation, together with the change in assemblage from Veryhachium-Micrhystridium to Micrhystridium-leiosphere dominance could thus be interpreted as a change from a distal to a more proximal setting, which would suggest a marine regression. Although this was once considered a possible cause of the late Permian extinction event (Hallam and Cohen, 1989), the current consensus is that eustatic sea-level fall occurred prior to collapse of marine ecosystems and the extinction, and the subsequent transition from the Permian to the Triassic happened during sea-level rise (Wignall and Hallam, 1992). In some East Greenland locations, apparently missing biozones and local erosive conglomeratic channels have been proposed as evidence for sea-level fall near the boundary between the Schuchert Dal and Wordie Creek formations (Surlyk et al., 1984), but Wignall and Twitchett (2002) demonstrated that in central Jameson Land the sedimentological changes are consistent with sea-level rise, and that the erosive, conglomeratic channels occur at multiple stratigraphic levels and postdate the extinction and PermianTriassic boundary.

Thus, during the extinction event the acritarch assemblage changes to a more typical nearshore assemblage, despite the ongoing sea-level rise. Instead of a marine regression, the observed shift in acritarch assemblages could be explained by an increase in run-off, which affects the nearshore environment by lowering surface water salinity and delivering nutrients, both of which are found to affect the distribution of modern phytoplankton (e.g. Bouimetarhan et al., 2009; Devillers and de Vernal, 2000; Pospelova et al., 2004; Zonneveld et al., 2013). Dinocyst morphology has also been linked to environmental conditions (e.g. Mertens et al., 2009, 2011), 
with salinity identified as an important factor influencing process length (Ellegaard et al., 2002; Mertens et al., 2011). Similarly, studies of acritarch process length and palaeoenvironment show that species and individuals with longer processes are generally found in more offshore locations, while in inshore settings acritarchs with shorter processes are more abundant (Lei et al., 2013b; Servais et al., 2004; Stricanne et al., 2004). The average process length of specimens belonging to the Micrhystridium breve group, shows a decreasing trend during the extinction interval, with higher values before the extinction event and lower values after the event (Fig. 6). The overall trend shows a shortening of on average $3-5 \mu \mathrm{m}$, which is substantially larger than the variability within one specimen. The trend is also gradual, in contrast to the facies changes, which are abrupt, and the shorter processes are thus not directly linked with stratification. Instead, the shortening of the processes could be interpreted as a lowering in salinity during the extinction event. Within the $2 \mathrm{~m}$ interval including the extinction interval $(-1$ to $+1 \mathrm{~m})$ there is also a small, offset in body size between samples from bioturbated and laminated rocks; however, this difference is not consistent when considering the full record. The body size of some dinocysts has been found to vary with temperature and salinity (e.g. Ellegaard et al., 2002; Mertens et al., 2012); however, the relationship has not been well studied. Possibly low-oxygen or low-salinity conditions or increased nutrient availability influenced acritarch body size in this interval. Run-off, lower salinity and salinity stratification together can explain the observed changes in palynofacies and acritarch records. In addition, transport of acritarchs with shorter processes from a nearshore environment into a deeper marine environment could also result in shorter average processes in the assemblage. However, this would result in a bimodal distribution of process length within one interval (nearshore specimens with shorter processes, and deep-water specimens with longer processes). Instead, process length, although variable within each interval, changes gradually (see also Fig. S1 in the Supplement). The changed environmental conditions continued through the aftermath of the biotic crisis, as shown by persistently low process lengths to the end of the study interval (Fig. 6). Meanwhile, the ongoing marine transgression likely resulted in the shoreward migration of oxygen-deficient waters, which explain the development of permanently anoxic conditions higher up in the Wordie Creek Formation (over 0.6-0.7 $\mathrm{m}$ from the formation boundary) (Mettam et al., 2017).

The development of widespread anoxia in the late Permian is usually explained by an expansion of anoxic deep waters onto the shelf (e.g. Grasby and Beauchamp, 2009). However, increased run-off and the development of estuarine circulation provide an alternative explanation for the development of anoxia in some shallow marine environments. Furthermore, low salinity is known to negatively impact biomass and size of modern marine invertebrates (e.g. Westerbom et al., 2002), and, along with higher temperatures and hypoxia, might also be a contributing factor in the size reduction of marine organisms recorded in the aftermath of the late Permian extinction event, as inferred for the bivalve Claraia in the Permian-Triassic section of East Greenland (Twitchett, 2007). Low-salinity conditions have previously been invoked to explain the dominance of the brachiopod lingulid in postextinction ecosystems (Zonneveld et al., 2007) because they are able to tolerate a wide range of salinities as well as hypoxia (e.g. Hammen and Lum, 1977). Lingulid fossils are found in many Permian-Triassic (shallow) marine sections (e.g. Peng et al., 2007) and the lowering of salinities in shallow marine settings and spreading anoxia provided ecological space for the lingulids (Peng et al., 2007; Rodland and Bottjer, 2001). It has been suggested that rising seawater temperatures in the Tethys resulted in strengthened monsoonal activity (e.g. Winguth and Winguth, 2012) and enhanced precipitation and run-off in the areas surrounding the Tethys (e.g. Parrish et al., 1982). Whether this would have had an effect on the study site is questionable because of its distance to the Tethys and relatively sheltered, inland position. Possibly river systems existed which brought freshwater to the Greenland-Norway basin from the south. It is also possible that rainfall increased locally. Mettam et al. (2017) speculated that changes in circulation patterns may have resulted in onshore winds bringing moist air to the study site. In addition vegetation destruction and soil erosion may also have contributed to enhanced run-off.

\subsection{Seawater temperature}

In addition to salinity, increasing water temperatures can also affect process length in dinocysts (e.g. Mertens et al., 2009, 2012) but this relationship is not always evident (e.g. Ellegaard et al., 2002). Seawater temperature reconstructions for the late Permian and Early Triassic exist mainly from carbonate-rich sections originating in the Tethys Ocean (e.g. Joachimski et al., 2012; Schobben et al., 2014; Sun et al., 2012). These reconstructions indicate increasing temperatures during the extinction event, and maximum temperatures are reached in the Early Triassic (e.g. Joachimski et al., 2012; Kearsey et al., 2009; Schobben et al., 2014; Sun et al., 2012). Since no water temperature reconstructions exist for the Greenland-Norway basin, at this time, it is not possible to exclude the effects of rising water temperatures on the acritarch morphology. Increasing water temperatures might be partly responsible for decreasing process length in acritarchs; however, a rising sea level in combination with rising temperatures is not able to explain the changes in the acritarch assemblages, which indicate a shift from more open marine to nearshore conditions.

Increased run-off cannot only explain the reconstructed changes in palynofacies and acritarch records, but in addition, a reduction in salinity also has significant implications for palaeotemperature reconstructions calculated from the oxygen isotopes of carbonates. Most Permian-Triassic 
temperature records are from the Tethys or surrounding areas, where monsoon activity has been proposed to increase (Winguth and Winguth, 2012) and thus salinity is expected to change as well. Permian-Triassic oxygen isotope data for palaeotemperature estimates have been derived from brachiopod shells (Kearsey et al., 2009) or conodont apatite (Joachimski et al., 2012; Schobben et al., 2014), with all studies concluding that temperature rose through the extinction event and that Early Triassic seas were "lethally hot" (Sun et al., 2012). Oxygen isotope values partially reflect seawater salinity, although this is generally ignored in palaeotemperature studies because there is currently no independent proxy of salinity change, and so it is assumed that salinity remained constant. If salinity was reduced in shelf seas due to hydrological changes (e.g. enhanced precipitation and run-off), as it appears for East Greenland at least, then all of these studies may have significantly overestimated Early Triassic temperatures. The actual temperature rise associated with the extinction event would have been lower and below "lethal" levels, which is more consistent with fossil evidence that the oceans were not completely devoid of life.

\section{Conclusions}

The highest-resolution palynological sampling yet attempted for the Fiskegrav location of central Jameson Land has shown significant millennial-scale changes in marine and terrestrial environments. The biotic crisis, defined by a peak in the spore: pollen ratio, which indicates widespread disruption and collapse of the terrestrial flora, postdates the onset of the carbon-isotope excursion. The spore : pollen peak spans $0.8 \mathrm{~m}$ of section, which, with current age estimates, gives an estimation of 1600 to 8000 years for the ecosystem collapse. This is much shorter than previous estimations. The onset of the biotic crisis does not appear to coincide with any obvious changes in lithology or sedimentary facies, and deposition of the shallow marine shelf sediments appears to have taken place under oxygenated waters. During the latter stages of the biotic crisis, laminated beds begin to appear, indicating periodic anoxic deposition. These laminated rocks contain palynological evidence for a more nearshore setting, which contradicts the widely accepted evidence that globally sea level was rising during the extinction event. A preferred alternative explanation, consistent with palynological assemblages, is that enhanced run-off, water column stratification and enhanced primary productivity led to the development of anoxic bottom waters. Enhanced run-off would lead to elevated freshwater flux into shallow shelf seas, which would have led to the development of a freshwater wedge, stratification and a reduction in salinity. Acritarch process length is considered here to be a proxy for seawater salinity and supports these inferred changes. Increased run-off did not immediately lead to anoxia, possibly because precipitation gradually increased during the extinction event until the fresh- water flow was large enough to cause water column stratification. Increasing seawater temperatures may have also affected acritarch morphology, and partially be responsible for the reduced process length. However, rising temperatures alone cannot explain the reconstructed changes in the palynofacies and acritarch records. In fact, seawater temperature reconstructions may overestimate the rise in water temperatures during the extinction event since possible changes in salinity are not included in the calculations.

Data availability. The data reported in this paper are available in tables in the Supplement.

\section{The Supplement related to this article is available online at https://doi.org/10.5194/cp-14-441-2018-supplement.}

Author contributions. WMK designed the study. RJT provided material. EEvS analysed the samples for palynofacies and palynomorph content and performed measurements on acritarchs. EEvS wrote the paper with input from WMK and RJT.

Competing interests. The authors declare that they have no conflict of interest.

Acknowledgements. This work was funded by the Norwegian Research Council, project 234005, The Permian/Triassic evolution of the Timan-Pechora and Barents Sea Basins. We thank Berit L. Berg and Mufak S. Naoroz for technical support. Samples were collected by Richard J. Twitchett, who thanks Gilles Cuny and the Danish National Research Foundation for logistic and financial support.

Edited by: Arne Winguth

Reviewed by: two anonymous referees

\section{References}

Algeo, T. J. and Twitchett, R. J.: Anomalous Early Triassic sediment fluxes due to elevated weathering rates and their biological consequences, Geology, 38, 1023-1026, https://doi.org/10.1130/G31203.1, 2010.

Balme, B. E.: Palynology of Permian-Triassic boundary beds at Kap Stosch, East Greenland, Nyt nordisk forlag, 200, 37 p., 1979.

Benton, M. J. and Twitchett, R. J.: How to kill (almost) all life: the end-Permian extinction event, Trends Ecol. Evol., 18, 358-365, https://doi.org/10.1016/S0169-5347(03)00093-4, 2003.

Bond, D. P. G. and Wignall, P. B.: Pyrite framboid study of marine Permian-Triassic boundary sections: A complex anoxic event and its relationship to contemporaneous mass extinction, GSA Bulletin, 122, 1265-1279, https://doi.org/10.1130/B30042.1, 2010 . 
Bouimetarhan, I., Marret, F., Dupont, L., and Zonneveld, K.: Dinoflagellate cyst distribution in marine surface sediments off West Africa $\left(17-6^{\circ} \mathrm{N}\right)$ in relation to sea-surface conditions, freshwater input and seasonal coastal upwelling, Mar. Micropaleontol., 71, 113-130, https://doi.org/10.1016/j.marmicro.2009.02.001, 2009.

Burgess, S. D. and Bowring, S. A.: High-precision geochronology confirms voluminous magmatism before, during, and after Earth's most severe extinction, Science Advances, 1, e1500470, https://doi.org/10.1126/sciadv.1500470, 2015.

Burgess, S. D., Muirhead, J. D., and Bowring, S. A.: Initial pulse of Siberian Traps sills as the trigger of the end-Permian mass extinction, Nat. Commun., 8, 164, https://doi.org/10.1038/s41467017-00083-9, 2017.

Clapham, M. E. and Payne, J. L.: Acidification, anoxia, and extinction: A multiple logistic regression analysis of extinction selectivity during the Middle and Late Permian, Geology, 39, 10591062, https://doi.org/10.1130/G32230.1, 2011.

Colbath, G. K. and Grenfell, H. R.: Review of biological affinities of Paleozoic acid-resistant, organic-walled eukaryotic algal microfossils (including "acritarchs"), Rev. Palaeobot. Palyno., 86, 287-314, https://doi.org/10.1016/0034-6667(94)00148-D, 1995.

Cui, Y. and Kump, L. R.: Global warming and the end-Permian extinction event: Proxy and modeling perspectives, Earth-Sci. Rev., 149, 5-22, https://doi.org/10.1016/j.earscirev.2014.04.007, 2015.

de Vernal, A., Hillaire-Marcel, C., Turon, J.-L., and Matthiessen, J.: Reconstruction of sea-surface temperature, salinity, and seaice cover in the northern North Atlantic during the last glacial maximum based on dinocyst assemblages, Can. J. Earth Sci., 37, 725-750, https://doi.org/10.1139/e99-091, 2000.

Devillers, R. and de Vernal, A.: Distribution of dinoflagellate cysts in surface sediments of the northern North Atlantic in relation to nutrient content and productivity in surface waters, Mar. Geol., 166, 103-124, https://doi.org/10.1016/S0025-3227(00)00007-4, 2000.

Ellegaard, M.: Variations in dinoflagellate cyst morphology under conditions of changing salinity during the last 2000 years in the Limfjord, Denmark, Rev. Palaeobot. Palyno., 109, 65-81, https://doi.org/10.1016/S0034-6667(99)00045-7, 2000.

Ellegaard, M., Lewis, J., and Harding, I.: Cyst-theca relationship, life cycle, and effects of temperature and salinity on the cyst morphology of Gonyaulax Baltica Sp. Nov. (dinophyceae) from the Baltic Sea Area, J. Phycol., 38, 775-789, https://doi.org/10.1046/j.1529-8817.2002.01062.x, 2002.

Evitt, W. R.: A discussion and proposals concerning fossil dinoflagellates, hystrichospheres, and acritarchs, I, P. Natl. Acad. Sci. USA, 49, 158-164, 1963.

Fischer, A. G.: Brackish oceans as the cause of the Permo-Triassic marine faunal crisis, in: Problems in Palaeoclimatology, edited by: Nairn, A. E. M., Interscience, London, 566-574, 1964.

Grard, A., François, L. M., Dessert, C., Dupré, B., and Goddéris, Y.: Basaltic volcanism and mass extinction at the PermoTriassic boundary: Environmental impact and modeling of the global carbon cycle, Earth Planet. Sc. Lett., 234, 207-221, https://doi.org/10.1016/j.epsl.2005.02.027, 2005.

Grasby, S. E. and Beauchamp, B.: Latest Permian to Early Triassic basin-to-shelf anoxia in the Sverdrup
Basin, Arctic Canada, Chem. Geol., 264, 232-246, https://doi.org/10.1016/j.chemgeo.2009.03.009, 2009.

Grasby, S. E., Beauchamp, B., Bond, D. P. G., Wignall, P., Talavera, C., Galloway, J. M., Piepjohn, K., Reinhardt, L., and Blomeier, D.: Progressive environmental deterioration in northwestern Pangea leading to the latest Permian extinction, Geol Soc. Am. Bull., B31197.1, https://doi.org/10.1130/B31197.1, 2015.

Hallam, A. and Cohen, J. M.: The Case for Sea-Level Change as a Dominant Causal Factor in Mass Extinction of Marine Invertebrates [and Discussion], Philos. T. Roy. Soc. B, 325, 437-455, https://doi.org/10.2307/2396934, 1989.

Hammen, C. S. and Lum, S. C.: Salinity tolerance and pedicle regeneration of Lingula, J. Paleontol., 51, 548-551, 1977.

Hotinski, R. M., Bice, K. L., Kump, L. R., Najjar, R. G., and Arthur, M. A.: Ocean stagnation and end-Permian anoxia, Geology, 29, 7-10, https://doi.org/10.1130/00917613(2001)029<0007:OSAEPA>2.0.CO;2, 2001.

Isozaki, Y.: Permo-Triassic Boundary Superanoxia and Stratified Superocean: Records from Lost Deep Sea, Science, 276, 235238, https://doi.org/10.1126/science.276.5310.235, 1997.

Jansonius, J.: Palynology of permian and triassic sediments, Peace River area, Western Canada, Palaeontogr. Abt. B, PhD thesis, 35 98, 1962.

Joachimski, M. M., Lai, X., Shen, S., Jiang, H., Luo, G., Chen, B., Chen, J., and Sun, Y.: Climate warming in the latest Permian and the Permian-Triassic mass extinction, Geology, 40, 195198, https://doi.org/10.1130/G32707.1, 2012.

Kearsey, T., Twitchett, R. J., Price, G. D., and Grimes, S. T.: Isotope excursions and palaeotemperature estimates from the Permian/Triassic boundary in the Southern Alps (Italy), Palaeogeogr. Palaeocl., 279, 29-40, https://doi.org/10.1016/j.palaeo.2009.04.015, 2009.

Korte, C. and Kozur, H. W.: Carbon-isotope stratigraphy across the Permian-Triassic boundary: A review, J. Asian Earth Sci., 39, 215-235, https://doi.org/10.1016/j.jseaes.2010.01.005, 2010.

Lei, Y., Servais, T., Feng, Q., and He, W.: The spatial (nearshoreoffshore) distribution of latest Permian phytoplankton from the Yangtze Block, South China, Palaeogeogr. Palaeocl., 363-364, 151-162, https://doi.org/10.1016/j.palaeo.2012.09.010, 2012.

Lei, Y., Servais, T., and Feng, Q.: The diversity of the Permian phytoplankton, Rev. Palaeobot. Palyno., 198, 145-161, https://doi.org/10.1016/j.revpalbo.2013.03.004, 2013a.

Lei, Y., Servais, T., Feng, Q., and He, W.: Latest Permian acritarchs from South China and the Micrhystridium/Veryhachium complex revisited, Palynology, 37, 325-344, https://doi.org/10.1080/01916122.2013.793625, 2013 b.

Li, J., Servais, T., Yan, K., and Zhu, H.: A nearshore-offshore trend in acritarch distribution from the Early-Middle Ordovician of the Yangtze Platform, South China, Rev. Palaeobot. Palyno., 130, 141-161, https://doi.org/10.1016/j.revpalbo.2003.12.005, 2004.

Looy, C. V., Twitchett, R. J., Dilcher, D. L., Van KonijnenburgVan Cittert, J. H., and Visscher, H.: Life in the endPermian dead zone, P. Natl. Acad. Sci. USA, 98, 7879-7883, https://doi.org/10.1073/pnas.131218098, 2001.

McGhee, G. R., Sheehan, P. M., Bottjer, D. J., and Droser, M. L.: Ecological ranking of Phanerozoic biodiversity crises: The Serpukhovian (early Carboniferous) crisis had a greater eco- 
logical impact than the end-Ordovician, Geology, 40, 147-150, https://doi.org/10.1130/G32679.1, 2012.

Mertens, K. N., Ribeiro, S., Bouimetarhan, I., Caner, H., Combourieu Nebout, N., Dale, B., De Vernal, A., Ellegaard, M., Filipova, M., Godhe, A., Goubert, E., Grøsfjeld, K., Holzwarth, U., Kotthoff, U., Leroy, S. A. G., Londeix, L., Marret, F., Matsuoka, K., Mudie, P. J., Naudts, L., Peña-Manjarrez, J. L., Persson, A., Popescu, S.-M., Pospelova, V., Sangiorgi, F., van der Meer, M. T. J., Vink, A., Zonneveld, K. A. F., Vercauteren, D., Vlassenbroeck, J., and Louwye, S.: Process length variation in cysts of a dinoflagellate, Lingulodinium machaerophorum, in surface sediments: Investigating its potential as salinity proxy, Mar. Micropaleontol., 70, 54-69, https://doi.org/10.1016/j.marmicro.2008.10.004, 2009.

Mertens, K. N., Dale, B., Ellegaard, M., Jansson, I.-M., Godhe, A., Kremp, A., and Louwye, S.: Process length variation in cysts of the dinoflagellate Protoceratium reticulatum, from surface sediments of the Baltic-Kattegat-Skagerrak estuarine system: a regional salinity proxy, Boreas, 40, 242-255, https://doi.org/10.1111/j.1502-3885.2010.00193.x, 2011.

Mertens, K. N., Bringué, M., Van Nieuwenhove, N., Takano, Y., Pospelova, V., Rochon, A., De Vernal, A., Radi, T., Dale, B., Patterson, R. T., Weckström, K., Andrén, E., Louwye, S., and Matsuoka, K.: Process length variation of the cyst of the dinoflagellate Protoceratium reticulatum in the North Pacific and BalticSkagerrak region: calibration as an annual density proxy and first evidence of pseudo-cryptic speciation, J. Quaternary Sci., 27, 734-744, https://doi.org/10.1002/jqs.2564, 2012.

Mettam, C., Zerkle, A. L., Claire, M. W., Izon, G., Junium, C. J., and Twitchett, R. J.: High-frequency fluctuations in redox conditions during the latest Permian mass extinction, Palaeogeogr. Palaeocl., 485, 210-223, https://doi.org/10.1016/j.palaeo.2017.06.014, 2017.

Mudie, P. J., Aksu, A. E., and Yasar, D.: Late Quaternary dinoflagellate cysts from the Black, Marmara and Aegean seas: variations in assemblages, morphology and paleosalinity, Mar. Micropaleontol., 43, 155-178, https://doi.org/10.1016/S03778398(01)00006-8, 2001.

Mudie, P. J., Rochon, A., Aksu, A. E., and Gillespie, H.: Dinoflagellate cysts, freshwater algae and fungal spores as salinity indicators in Late Quaternary cores from Marmara and Black seas, Mar. Geol., 190, 203-231, https://doi.org/10.1016/S00253227(02)00348-1, 2002.

Pacton, M., Gorin, G. E., and Vasconcelos, C.: Amorphous organic matter - Experimental data on formation and the role of microbes, Rev. Palaeobot. Palyno., 166, 253-267, https://doi.org/10.1016/j.revpalbo.2011.05.011, 2011.

Parrish, J. T., Ziegler, A. M., and Scotese, C. R.: Rainfall patterns and the distribution of coals and evaporites in the Mesozoic and Cenozoic, Palaeogeogr. Palaeocl., 40, 67-101, https://doi.org/10.1016/0031-0182(82)90085-2, 1982.

Peng, Y., Shi, G. R., Gao, Y., He, W., and Shen, S.: How and why did the Lingulidae (Brachiopoda) not only survive the end-Permian mass extinction but also thrive in its aftermath?, Palaeogeogr. Palaeocl., 252, 118-131, https://doi.org/10.1016/j.palaeo.2006.11.039, 2007.

Piasecki, S.: Preliminary palynostratigraphy of the Permian-Lower Triassic sediments in Jameson Land and Scoresby Land, East Greenland, B. Geol. Soc. Denmark, 32, 139-144, 1984.
Pospelova, V., Chmura, G. L., and Walker, H. A.: Environmental factors influencing the spatial distribution of dinoflagellate cyst assemblages in shallow lagoons of southern New England (USA), Rev. Palaeobot. Palyno., 128, 7-34, https://doi.org/10.1016/S0034-6667(03)00110-6, 2004.

Rodland, D. L. and Bottjer, D. J.: Biotic Recovery from the End-Permian Mass Extinction: Behavior of the Inarticulate Brachiopod Lingula as a Disaster Taxon, PALAIOS, 16, 95-101, https://doi.org/10.1669/08831351(2001)016<0095:BRFTEP>2.0.CO;2, 2001.

Sarjeant, W. A. S.: Acritarchs and tasmanitids form the Chhidru Formation, uppermost Permian of West Pakistan, Stratigraphic Boundary Problems: Permian and Triassic of West Pakistan, Spec. Publ., 4, 277-304, 1970.

Sarjeant, W. A. S. and Stancliffe, R. P. W.: The Micrhystridium and Veryhachium Complexes (Acritarcha: Acanthomorphitae and Polygonomorphitae): A Taxonomic Reconsideration, Micropaleontology, 40, 1-77, https://doi.org/10.2307/1485800, 1994.

Schobben, M., Joachimski, M. M., Korn, D., Leda, L., and Korte, C.: Palaeotethys seawater temperature rise and an intensified hydrological cycle following the endPermian mass extinction, Gondwana Res., 26, 675-683, https://doi.org/10.1016/j.gr.2013.07.019, 2014.

Sephton, M. A., Looy, C. V., Brinkhuis, H., Wignall, P. B., De Leeuw, J. W., and Visscher, H.: Catastrophic soil erosion during the end-Permian biotic crisis, Geology, 33, 941-944, 2005.

Servais, T., Stricanne, L., Montenari, M., and Pross, J.: Population dynamics of galeate acritarchs at the Cambrian-Ordovician transition in the Algerian Sahara, Palaeontology, 47, 395-414, https://doi.org/10.1111/j.0031-0239.2004.00367.x, 2004.

Shen, J., Lei, Y., Algeo, T. J., Feng, Q., Servais, T., Yu, J., and Zhou, L.: Volcanic effects on microplankton during the Permian-Triassic transition (Shangsi and Xinmin, South China), PALAIOS, 28, 552-567, https://doi.org/10.2110/palo.2013.p13$014 \mathrm{r}, 2013$.

Sluijs, A. and Brinkhuis, H.: A dynamic climate and ecosystem state during the Paleocene-Eocene Thermal Maximum: inferences from dinoflagellate cyst assemblages on the New Jersey Shelf, Biogeosciences, 6, 1755-1781, https://doi.org/10.5194/bg-61755-2009, 2009.

Stemmerik, L. A. R. S., Bendix-Almgreen, S. E., and Piasecki, S.: The Permian-Triassic boundary in central East Greenland: past and present views, B. Geol. Soc. Denmark, 48, 159-167, 2001.

Stevens, C. H.: Was development of brackish oceans a factor in Permian extinctions?, Geol. Soc. Am. Bull., $\quad 88, \quad 133-138, \quad$ https://doi.org/10.1130/00167606(1977)88<133:WDOBOA>2.0.CO;2, 1977.

Stricanne, L., Munnecke, A., Pross, J., and Servais, T.: Acritarch distribution along an inshore-offshore transect in the Gorstian (lower Ludlow) of Gotland, Sweden, Rev. Palaeobot. Palyno., 130, 195-216, https://doi.org/10.1016/j.revpalbo.2003.12.007, 2004.

Sun, Y., Joachimski, M. M., Wignall, P. B., Yan, C., Chen, Y., Jiang, H., Wang, L., and Lai, X.: Lethally hot temperatures during the Early Triassic greenhouse, Science, 338, 366-370, https://doi.org/10.1126/science.1224126, 2012.

Surlyk, F., Piasecki, S., Rolle, F., Stemmerik, L., Thomsen, E., and Wrang, P.: The Permian base of East Greenland, in: Petroleum 
Geology of the North European Margin, edited by: Spencer, A. M., 303-315, Springer, the Netherlands, 1984.

Svensen, H., Planke, S., Polozov, A. G., Schmidbauer, N., Corfu, F., Podladchikov, Y. Y., and Jamtveit, B.: Siberian gas venting and the end-Permian environmental crisis, Earth Planet. Sc. Lett., 277, 490-500, https://doi.org/10.1016/j.epsl.2008.11.015, 2009.

Tappan, H. and Loeblich, A. R.: Evolution of the oceanic plankton, Earth-Sci. Rev., 9, 207-240, https://doi.org/10.1016/00128252(73)90092-5, 1973.

Twitchett, R. J.: The Lilliput effect in the aftermath of the endPermian extinction event, Palaeogeogr. Palaeocl., 252, 132-144, https://doi.org/10.1016/j.palaeo.2006.11.038, 2007.

Twitchett, R. J., Looy, C. V., Morante, R., Visscher, H., and Wignall, P. B.: Rapid and synchronous collapse of marine and terrestrial ecosystems during the end-Permian biotic crisis, Geology, 29, 351-354, https://doi.org/10.1130/00917613(2001)029<0351:RASCOM>2.0.CO;2, 2001.

Tyson, R. V.: Sedimentary Organic Matter, Organic Facies and Palynofacies, London, Chapman \& Hall, 615 p., 1995.

Wall, D.: Microplankton, pollen, and spores from the lower Jurassic in Britain, Micropaleontology, 11, 151-190, https://doi.org/10.2307/1484516, 1965.

Westerbom, M., Kilpi, M., and Mustonen, O.: Blue mussels, Mytilus edulis, at the edge of the range: population structure, growth and biomass along a salinity gradient in the north-eastern Baltic Sea, Mar. Biol., 140, 991-999, https://doi.org/10.1007/s00227-001-0765-6, 2002.

Wignall, P. B. and Hallam, A.: Anoxia as a cause of the Permian/Triassic mass extinction: facies evidence from northern Italy and the western United States, Palaeogeogr. Palaeocl., 93, 21-46, https://doi.org/10.1016/0031-0182(92)90182-5, 1992.
Wignall, P. B. and Twitchett, R. J.: Oceanic anoxia and the end Permian mass extinction, Science, 272, 1155-1158, 1996.

Wignall, P. B. and Twitchett, R. J.: Permian-Triassic sedimentology of Jameson Land, East Greenland: incised submarine channels in an anoxic basin, J. Geol. Soc., 159, 691-703, https://doi.org/10.1144/0016-764900-120, 2002.

Winguth, A. and Winguth, C.: Precession-driven monsoon variability at the Permian-Triassic boundary - Implications for anoxia and the mass extinction, Global. Planet. Change, 105, 160-170, https://doi.org/10.1016/j.gloplacha.2012.06.006, 2012.

Yin, H. (Ed.): The Palaeozoic-Mesozoic boundary, candidates of Global Stratotype Section and Point of the Permian-Triassic boundary, China University of Geosciences Press, Wuhan, 1996.

Zonneveld, J.-P., Beatty, T. W., and Pemberton, S. G.: Lingulide Brachiopods and the Trace Fossil Lingulichnus from the Triassic of Western Canada: Implications for Faunal Recovery After the End-Permian Mass Extinction, PALAIOS, 22, 74-97, https://doi.org/10.2110/palo.2005.p05-103r, 2007.

Zonneveld, K. A. F., Marret, F., Versteegh, G. J. M., Bogus, K., Bonnet, S., Bouimetarhan, I., Crouch, E., de Vernal, A., Elshanawany, R., Edwards, L., Esper, O., Forke, S., Grøsfjeld, K., Henry, M., Holzwarth, U., Kielt, J.-F., Kim, S. Y., Ladouceur, S., Ledu, D., Chen, L., Limoges, A., Londeix, L., Lu, S.-H., Mahmoud, M. S., Marino, G., Matsouka, K., Matthiessen, J., Mildenhal, D. C., Mudie, P., Neil, H. L., Pospelova, V., Qi, Y., Radi, T., Richerol, T., Rochon, A., Sangiorgi, F., Solignac, S., Turon, J.-L., Verleye, T., Wang, Y., Wang, Z., and Young, M.: Atlas of modern dinoflagellate cyst distribution based on 2405 data points, Rev. Palaeobot. Palyno., 191, 1197, https://doi.org/10.1016/j.revpalbo.2012.08.003, 2013. 